\title{
Level of Metal Pollutants in Water from Nyakomisaro Stream through Kisii Town
}

\author{
Omoko Bochaberi Janes ${ }^{1}$, Onyatta John ${ }^{2}$, Nyabaro Obed ${ }^{3}$, Kenanda Okemwa Evans ${ }^{4}$ \\ ${ }^{1,3,4}$ Kisii University \\ ${ }^{2}$ University of Nairobi
}

\begin{abstract}
Heavy metals are major pollutants of water sources. The source of these heavy metals is mostly from domestic, agricultural and industrial activities. Their presence in water even in low concentrations poses significant environmental concern. This study was conducted to access the levels of cadmium, copper, lead and zinc metals in water from Nyakomisaro stream. The study showed that mean concentration of these metals were: $0.074 \mathrm{ppm} \mathrm{Cd}, 2.228 \mathrm{ppm} \mathrm{Cu}, 1.401 \mathrm{ppm} \mathrm{Pb}$ and $0.141 \mathrm{ppm} \mathrm{Zn}$. The study concluded that the concentrations of cadmium and lead metals in Nyakomisaro stream water were higher than WHO recommended limit in drinking water thus, posing immediate fears of bio-accumulation.
\end{abstract}

Keywords: Heavy metal, bioaccumulation, cadmium, lead, copper, zinc

\section{Introduction}

Environmental pollution is currently one of the major issues facing humanity. It has increased exponentially in the past few years and reached alarming levels in terms of its effects on living creatures (Renge et al., 2012). The presence of toxic metals in the environment and more specifically in the various water sources is of major concern because of their toxicity, non-biodegradable nature and threat to human, animal and plant life. According to Kadirvelu et al., (2001) electroplating, painting, metallurgical, mining, textile, municipal, incineration and chemical manufacturing industries all generate toxic metals at various levels.

Toxic metal ions enter into water and soil from different waste-water sources. As a result they pollute the water streams and soil. A number of crops and aquatic plants take up these metals and bio-accumulate them. As trace elements, some of the heavy metals such as Copper and Zinc are essential to maintain the metabolism of the human body however at high concentrations and accumulated levels they could be poisonous. According to Ocharo and Bokea (2014), the concern over the pollution of Nyakomisaro stream has been raised by the regulatory authorities who have cited activities such as car wash centres and damping sites along Nyakomisaro stream as the cause, hence recommending cleanup.

The aim of this study was to access the concentrations of cadmium, copper, lead and zinc metals in water sampled from Nyakomisaro stream.

\section{Materials and Methods}

Water samples were collected from nine different sites of Nyakomisaro stream through Kisii Town. The distance between two successive sampling sites was approximately $0.55 \mathrm{~km}$. Samples were collected during a dry period in the month of September 2015 and in the wet season during the month of October the same year. Samples were collected in the morning, mid-day and in the evening. The water samples were collected in clean labeled polypropylene plastic bottles and stored in a refrigerator at $277 \mathrm{~K}$ and later they were transported to the laboratory for analysis.

Inductively Couple Plasma Emission (ICPE) spectrometer was used in the analysis. The concentrations of the metals were determined in triplicates and the mean values were used in data analysis. The accuracy and precision of the analytical procedure were determined.

\section{Results and Discussion}

Heavy metal concentration in the stream water during dry and wet season

The average concentration of cadmium was found to be $0.073 \mathrm{ppm}$ and $0.071 \mathrm{ppm}$ during the dry and wet seasons respectively (Figure 1). These levels indicated that Nyakomisaro water was contaminated with cadmium metal ions as they were more than $0.003 \mathrm{mg} / \mathrm{L}$ which is the recommended cadmium limit for drinking water (WHO, 1989). Copper level was found to range from $1.121 \mathrm{ppm}$ to $3.775 \mathrm{ppm}$ and from $0.228 \mathrm{ppm}$ to $3.784 \mathrm{ppm}$ during the dry and wet seasons respectively. Zinc level ranged from 0.137 $\mathrm{ppm}$ to $0.146 \mathrm{ppm}$ and from $0.136 \mathrm{ppm}$ to $0.145 \mathrm{ppm}$ during the dry and wet seasons respectively. With respect to the WHO limits of copper and zinc in drinking water, the levels did not constitute immediate toxicity to human beings (WHO, 1989; Agatha, 2010). Analysis of the stream water showed the concentration of $\mathrm{Cd}^{2+}, \mathrm{Cu}^{2+}$, and $\mathrm{Zn}^{2+}$ ions were higher in the dry season with mean values of 0.073 ppm, $2.228 \mathrm{ppm}, 0.141 \mathrm{ppm}$ respectively than in the wet season which had mean values of $0.071 \mathrm{ppm}, 1.965 \mathrm{ppm}$, $0.140 \mathrm{ppm}$ respectively (Figure 1). This was due to increase in temperature which attributed to the high rate of evaporation during the dry season, resulting in high concentration of these metals in the river. The wet season could have contributed to the dilution of water body, therefore, low concentration of these metals were recorded. Lead concentration was found to range from $1.36 \mathrm{ppm}$ to 1.413 and from $1.366 \mathrm{ppm}$ to $1.482 \mathrm{ppm}$ during the dry and wet seasons respectively. Lead $\left(\mathrm{Pb}^{2+}\right)$ showed low concentration of mean value $1.388 \mathrm{ppm}$ during the dry season compared to $1.398 \mathrm{ppm}$ in the wet period. A study on 


\section{International Journal of Science and Research (IJSR) \\ ISSN (Online): 2319-7064 \\ Index Copernicus Value (2013): 6.14 | Impact Factor (2015): 6.391}

heavy metal concentration in Nairobi dam water showed the same trend (Ndeda et al. 2014). This can be attributed to rainfall that was followed by high waste-water discharge from upstream environment (Kar et al., 2008; Khan et al., 1998). Lead $\left(\mathrm{Pb}^{2+}\right)$ concentration in the water samples was higher than $0.001 \mathrm{mg} / \mathrm{L}$ which is the WHO recommended limit in drinking water, thus, posing immediate fears of bio- accumulation (WHO, 1989). It was evident from the results that the order of heavy metal concentration was $\mathrm{Cu}^{2+}>\mathrm{Pb}^{2+}$ $>\mathrm{Zn}^{2+}>\mathrm{Cd}^{2+}$. Copper concentration in the sample was approximately twice the concentration of lead and about seventeen times that of zinc. The high concentration of copper ions in the stream can be attributed to agricultural runoff from farms using copper-based pesticides.

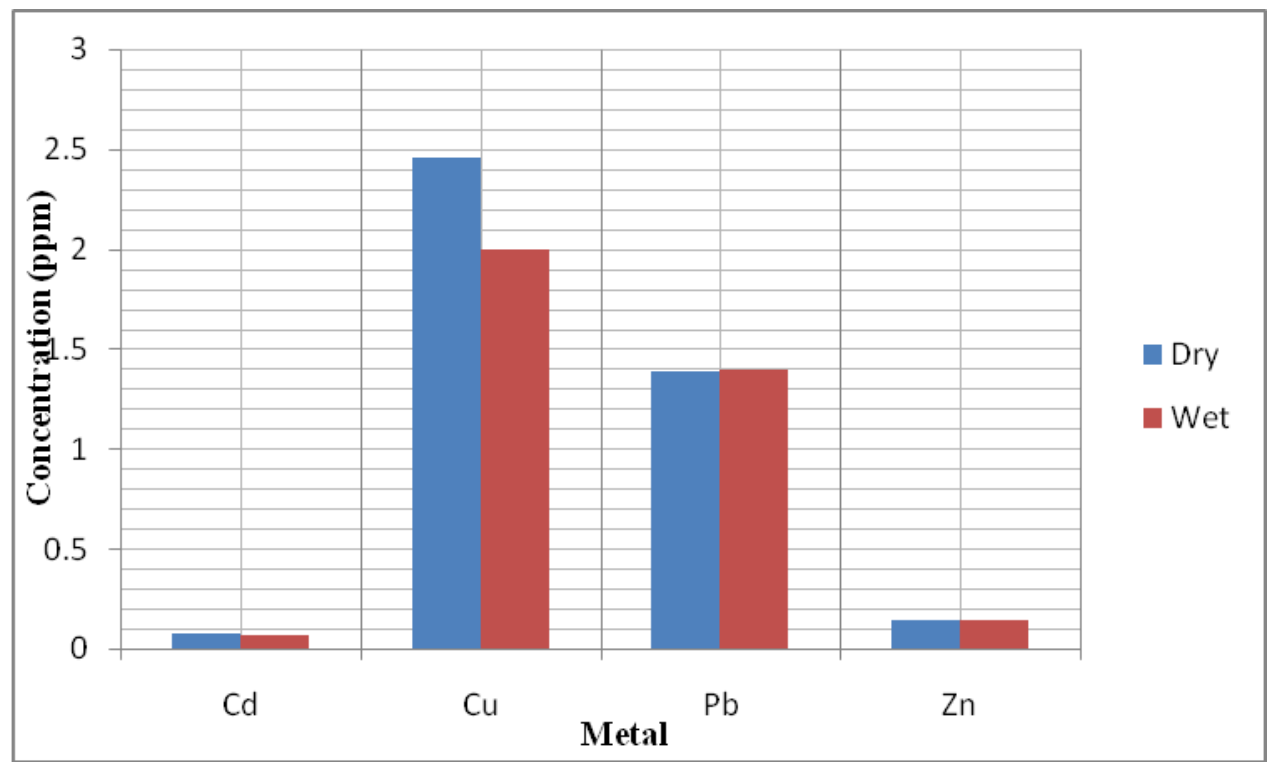

Figure 1: Seasonal variation of heavy metal concentrations in samples

\section{Conclusion}

It is concluded that, with respect to the WHO limits of copper and zinc in drinking water, the levels in this study did not constitute immediate toxicity to human beings. Lead $\left(\mathrm{Pb}^{2+}\right)$ and cadmium ion concentrations in the water samples were higher than $0.001 \mathrm{mg} / \mathrm{L}$ and $0.003 \mathrm{mg} / \mathrm{L}$ respectively which are the WHO recommended limit in drinking water, thus, posing immediate fears of bio-accumulation.

\section{References}

[1] Agatha A. N. (2010). Levels of some heavy metals in Tissues of Bonga Fish, Ethmallosafimbriata from Forcados River. Journal of Applied Environmental and Biological Sciences 1:44-47.

[2] Kadirvelu K., Thormaraiselvi K. and Namasivayam C. (2001). Removal of heavy metals from industrial waste water by Adsorption onto Activated carbon prepared from agricultural solid waste. Bioresource Techology, 76:63-65.

[3] Kar D., Sur P., Mandal S. K., Saha T. and Kole R. K. (2008). Assessment of heavy metal pollution in surface water. International Journal of environmental Sciences and Technology, 5:119-124

[4] Khan Y. S. A., Hossain M. S., Hossain S. M. G. A. and Halimuzzaman A. H. M. (1998). An environment of trace metals in the GBM Estuary. Journal of remote sensing and environment, 2:103-113

[5] Ndeda L. A. and Manohar S. (2014). Determination of heavy metals in Nairobi Dam water. Journal of Environmental Science, Technology and food Technology, 8:69
[6] Ocharo and Bokea (2014). Reality Stinks for Kisii Faces Consequences of its high Population. www.kisii.com/the news/3651. 1st August 2014

[7] Renge V. C., Khedkar S. V. and Pande V. (2012). Removal of heavy metals from wastewater using low cost adsorbents. Scientific Reviews and Chemical Communications 2:67-78

[8] World Health Organization (1989). Heavy metalsenvironmental aspects. Environmental Health criteria. No. 85. Geneva, Switzerland 